\title{
Plasma lipids and prothrombin time in rats fed palm oil and other commonly used fats in Egypt
}

\author{
By Mona M. Hussein (*), Fawzy M. Salama (**) and Karina M. Ebada (**). \\ $\left({ }^{*}\right)$ Food Science and Nutrition Dept., and \\ $\left({ }^{\star *}\right)$ Fat and Oil Dept., National Research Centre, Dokki, Cairo, Egypt.
}

RESUMEN

Lípidos en plasma y tiempo de protrombina en ratas alimentadas con aceite de palma y otras grasas frecuentemente utilizadas en Egipto.

Ratas Sprague-Dawley fueron alimentadas durante un periodo total de 8 semanas con seis dietas diferentes en su contenido graso. El contenido graso fue proporcionado por aceite de palma u oleína de palma o aceite de maiz o grasa hidrogenada o aceite de palma de fritura y mezcla de aceite de maíz + grasa hidrogenada en la relación (1:1). El último fue dado al grupo de control.

Los animales alimentados con las diferentes dietas experimentales mostraron diferencias significativas estadísticamente en el contenido en colesterol y triglicéridos en suero entre todos los grupos. El aumento en contenido HDL-colesterol fue evidente en animales alimentados con oleína de palma y aceite de palma. El grupo alimentado con aceite de fritura mostró el más bajo contenido en HDL-colesterol. En estos experimentos, los animales alimentados con oleína de palma mostraron la mayor relación de HDL-colesterol a colesterol total, mientras que la relación más baja fue mostrada en ratas alimentadas con aceite de fritura. El tiempo de protrombina (PT) y tromboplastina parcialmente activada (PTT) mostró valores elevados en dietas de aceite de palma, oleína de palma y aceite de maiz al comparar estos grupos con los demás.

PALABRAS-CLAVE: Dieta grasa - Lípidos en plasma - Rata - Tiempo de protrombina.

\section{SUMMARY}

Plasma lipids and prothrombin time in rats fed palm oil and other commonly used fats in Egypt.

Sprague-Dawley rats were fed for a total period of 8 weeks on six diets that were different in the source of their fat content. The fat content was provided either, palm oil or palm olein or corn oil or hydrogenated fat, or frying palm oil and mixture of corn oil + hydrogenated fat in the ratio (1:1). The latter was given to the control group. Animals fed these various experimental diets showed statistically significant differences in serum cholesterol and serum triglycerides content among all group. Increased HDL-cholesterol content was evident in animals fed on palm-olein and palm oil. The frying oil fed group showed lowest HDL-cholesterol content. In these experiments palm olein fed animals showed highest ratio of $\mathrm{HDL}$-cholesterol to total cholesterol while the lowest ratio was shown in rats fed on frying oil. Prothrombin (PT) and activated partial thromboplastin time (PTT) showed higher values in palm oil, palm olein and corn oil diets as compared to all groups with each other.

KEY-WORDS: Fatty diet-Plasma lipids - Prothrombin time - Rat.

\section{INTRODUCTION}

The consumption of palm oil has increased significantly in Egypt during the last few years as compared with other edible oils. It has been used for several purposes such as cooking, frying and in several food industries.

The use of palm oil in food products has recently been called into questions about its effect on health aspects. Several controversial reports have been published that compare palm oil with soy oil (1). At the same time, palm oil has a very low ratio of polyunsaturated to saturated fatty acids (2). It is well established that diets high in saturated fatty acids represent a major factor in the induction of plasma hyperlipidemia and exerts its effects in the process of atherogenesis and coronary heart diseases (3), (4).

Sundram et al (5) studied the effect of dietary palm oil and its fraction on rat blood lipids using semisynthetic purified diet containing $20 \%$ fat for 15 weeks. The dietary fats were corn oil, soybean oil, palm oil, palm olein, and palm stearin. No significant difference in the body and organs weights of rats fed the various diets were evident. Plasma cholesterol levels of rats fed soybean oil were significantly lower than those of rats fed corn oil, palm oil, palm olein or palm stearin.

Frying is one of the most commonly used procedures for the preparations of foods with desirable texture and flavor, various vegetable oils are used for frying of food products (6).

Various chemical changes such as hydrolysis, oxidation and polymerization occur in the frying oil as consequence of the frying process (high temperature, the presence of water vapour content of the oil surface with air, the presence of fried product particles in the system) (7). Overused or highly a bused frying oils contain oxidized and polymerized materials that might be harmful to human health (8).

The aim of the present work is to evaluate palm oil compared with other commonly used fats and oils available in our market. These are corn oil, hydrogenated fat, palm olein and frying palm oil. To fulfill these objectives feeding experiments were carried out and serum lipids, prothrombin time (PT) and activated partial thromboplastin time (PTT) were determined. 


\section{EXPERIMENTAL}

\subsection{Material and Methods}

The dietary test fats used in the present investigation were selected on basis of wide consumption by Egyptian population. These include: Palm oil and palm olein which are products of Misr Gulf Oil Processing Co. These fats were delivered by the company without storing in the local market. The frying oil sample was drawn from a closed system from Egypt Trade Chipsy Co. at a temperature of nearly $180^{\circ} \mathrm{C}$. Also, the turnover rate (the rate at which fresh oil is added to the fryer to replace oil lost from the system), affects to a great extent the keeping quality of the oil. Corn oil and hydrogenated fat were brought from local market. The hydrogenated fat was used to make of blend of hydrogenated corn oil to give fat of iodine value (65.7). Time of hydrogenation 20 minutes, used $\mathrm{Ni}$ as a catalyst, at $180^{\circ} \mathrm{C}$ at atmospheric pressure. The source of corn oil is byproduct of starch industry.

Nutritional studies were carried out in sprague Dawley albino rats that weighed $100 \pm 10 \mathrm{~g}$.

The animals were divided into six groups, 6 rats in each group, the animals were kept individually in wire bottomed cages at $25 \pm 2{ }^{\circ} \mathrm{C}$ and relative humidity $55 \%$. Food and water were given ad libitum. Six isocaloric diets were prepared as shown in Table I.

Table I

\section{Composition of the experimental diets $(\mathrm{g} / 100 \mathrm{~g})$}

\begin{tabular}{cc}
\hline INGREDIENTS & DIET \% \\
\hline Casein & 15.0 \\
Fat $\left(^{*}\right)$ & 15.0 \\
Sucrose & 22 \\
Starch & 43 \\
Salt mixture (9) & 4 \\
Vitamin mixture (10) & 1 \\
\hline TOTAL & $\mathbf{1 0 0}$ \\
\hline
\end{tabular}

(*) The dietary fats used are: palm oil, palm olein, frying oil, corn oil, hydrogenated fat and a mixture of corn oil hydrogenated fat (1:1) WM as control group.

The feeding experiments tested for 8 weeks. During the experimental feeding period the animals were carefully monitored and checked for food consumption and change in body weight.

On the last day, animals were fasted overnight, the animals were sacrificed. Blood was collected and sera was separated.

Serum samples were analyzed for total lipid (11), serum total cholesterol (12), triglycerides (13), high density lipoprotein cholesterol (phosphotungstate magnesium precipitation method) (14), phospholipids (15).

One $\mathrm{ml}$ of blood was taken on sodium citrate as anticoagulant for determination of prothrombin time (PT) and activated partial thromboplastin time (PTT) (16).

\subsection{Statistical Technique}

The standard deviation (SD) was used to measure the variation of a particular determination or parameter. Where appropriate the one-way analysis of variance (ANOVA) was used to compute for differences in total lipid, phospholipids, cholesterol, triglycerides, HDL-cholesterol., PT and PTT, among the various experimental groups, using $\mathrm{F}$ : 0.05 as the level of significance (17).

\section{RESULTS AND DISCUSSION}

The results shown in tables II, III and IV revealed that there are significant differences between the all groups as regards serum total lipids decreased in groups fed corn oil and frying oil. These findings contradict with those reported by seham and Maher who noticed that serum lipids pattern of rats fed the heated oil was increased. The discrepancy might be due to the relatively lower food intake in the present study. This is may be attributed to loss of appetite of rats due to the formation of harmful products such as peroxides and thermalpolymers which were formed during the frying process (18).

Table II

Comparison of lipids in different experimental groups $(\mathrm{mg} / \mathrm{dL})$

\begin{tabular}{ccrrrrr}
\hline GROUP & & T.L. & T.ch. & T.G. & Ph.L. & HDL.ch. \\
\hline Corn oil & Mean & 471.75 & 68.5 & 64.63 & 77.36 & 25.52 \\
& S.D \pm & 27.14 & 2.86 & 2.78 & 5.51 & 2.97 \\
\hline Palm olein & Mean & 530.66 & 68.52 & 141.72 & 80.05 & 28.33 \\
& S.D \pm & 10.01 & 4.25 & 6.09 & 2.76 & 2.06 \\
\hline Palm oil & Mean & 527.84 & 84.28 & 90.01 & 82.95 & 30.18 \\
& S.D \pm & 13.40 & 1.93 & 8.47 & 10.56 & 3.18 \\
\hline Control & Mean & 551.74 & 76.20 & 115.00 & 82.22 & 23.33 \\
& S.D \pm & 13.82 & 9.36 & 8.92 & 3.52 & 1.86 \\
\hline Hydrogenated & Mean & 622.33 & 72.48 & 163.66 & 82.16 & 22.08 \\
fat & S.D \pm & 20.76 & 6.03 & 6.65 & 5.19 & 1.20 \\
\hline Frying oil & Mean & 462.31 & 71.26 & 98.50 & 78.93 & 19.15 \\
& S.D \pm & 30.73 & 4.61 & 14.78 & 6.21 & 1.44 \\
\hline & F. & & & & & \\
& & .0000 & 0.0001 & .0000 & 0.584 & 0.000 \\
\hline
\end{tabular}

- Mean of 6 rats per experimental groups least significant difference by one-way ANOVA for $\alpha=0.05$ significant.

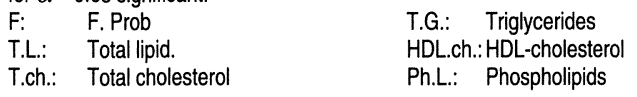

Table III

The atherogenic potency of dietary fats (the ratio of HDL-cholesterol to total cholesterol)

\begin{tabular}{ccccccc}
\hline RATIO & Control & $\begin{array}{c}\text { Palm } \\
\text { olein }\end{array}$ & $\begin{array}{c}\text { Palm } \\
\text { oil }\end{array}$ & $\begin{array}{c}\text { Frying } \\
\text { oil }\end{array}$ & $\begin{array}{c}\text { Corn } \\
\text { oil }\end{array}$ & $\begin{array}{c}\text { Hydrogenated } \\
\text { fat }\end{array}$ \\
\hline $\begin{array}{c}\text { HDL-cholesterol } \\
\text { Total cholesterol }\end{array}$ & 0.306 & 0.413 & 0.360 & 0.268 & 0.368 & 0.305 \\
\hline
\end{tabular}


Table IV

Comparison of Thromboplastin (PT) Partial Thromboplastin time (PTT) different experimental groups

\begin{tabular}{cccc}
\hline GROUP & & $\begin{array}{c}\text { Thromboplastin time } \\
\text { (PT) }\end{array}$ & $\begin{array}{c}\text { Partial thromboplastin time } \\
\text { (PTT) }\end{array}$ \\
\hline Corn oil & Mean & 19 & 37.66 \\
& S.D \pm & 1.44 & 2.58 \\
\hline Palm olein & Mean & 17.16 & 35.83 \\
& S.D \pm & 1.94 & 1.53 \\
\hline Palm oil & Mean & 15.66 & 43.11 \\
& S.D \pm & 0.95 & 3.9 \\
\hline Control & Mean & 13.66 & 32.5 \\
& S.D \pm & 1.03 & 3.83 \\
\hline Hydrogenated & Mean & 14.25 & 25.83 \\
fat & S.D \pm & 1.29 & 3.06 \\
\hline Frying oil & Mean & 14.08 & 27.91 \\
& S.D \pm & 1.02 & 7.22 \\
\hline \multirow{2}{*}{. } & F. & .000 & .000 \\
\hline
\end{tabular}

- Mean of 6 rats per experimental groups least significant difference by one-way ANOVA for $\alpha=0.05$ significant.

F: F. Prob.

The data from the present work show that serum triglycerides are the main serum lipid fraction, and can be modified in response to different diets.

Triglycerides are lowest in the corn oil diet, followed by palm oil, frying oil, palm olein and hydrogenated fat respectively. These results are in agreement with Majumdar et al (19), who recorded lower values of plasma triglycerides in case of palm oil diet.

The same finding was observed by, Habidah Abdul Hamid et al (20) revealed the same observation as regards the lowering action of palm oil on plasma triglycerides. Contrary to this, some workers observed elevated levels of plasma triglycerides in rats fed on palm oil (21) (22) (23).

It should be mentioned that Tony et al (24) could not record significant changes for serum triglycerides throughout their study on rats fed palm olein, corn oil and coconut oil. Also Murakumi et al (25) found no significant differences in the concentration of triglycerides in serum among rats fed palm oil, palm olein or soybean oil. These discrepancies might be due to the difference in diet composition concerning the serum phospholipids, all the groups showed a nonsignificant change when compared with each either.

The corn oil fed rats having the lowest value while palm oil fed rats had the highest value. Some workers (4) (5) (23) found that serum phospholipids content was increased in palm oil group when compared to corn oil group which is in agreement with our results.

Plasma total cholesterol show statistically significant differences between all groups receiving different oils and fats including the different palm oil constituents which show a tendency for higher cholesterol level. It is generally believed that saturated fat from animal and vegetable sources in human diets tend to cause an elevation of serum cholesterol concentration (26). Hornstra et al (27) found that palm oil is an exception in having a lipid lowering effect despite its high concentration of saturated fatty acid $(50 \%$ palmitic acid). These results agreed with Qureshi et al (28) who found that total serum cholesterol was reduced on feeding palm oil diet when compared to corn oil diet. Some authors (29) demonstrated the hypocholesterolemic effect of palm oil and corn oil, too.

A possible explanation for this apparently paradoxical action the high content of tocotrienols present in palm oil (780-1080 $\mu \mathrm{g} / \mathrm{g})$. Recently, Sugano and Imaizumi (30) reported that palm oil is hypercholesterolemic when compared with polyunsaturated fatty acid rich diet. They stated that such specific effect appear to attributed to the fatty acid profile of different fats and oils.

With respect to HDL-cholesterol, all the groups showed significant changes when compared with each other. The palm oil group showed an increase in HDL-cholesterol. These results agree with those found by some investigators (31) who recorded in a human study, a highest level of $\mathrm{HDL}$-cholesterol in the group consuming palm oil diet $(\mathrm{P} / \mathrm{s}$ 0.2 ) with respect to other fats having different $P / s$ ratios.

The ratio of $\mathrm{HDL}$-cholesterol to total lipid cholesterol was calculated in table III. It was suggested to give an indication of the atherogenis potency of a dietary fat. An increased ratio to indicates less potency of the dietary fat (4).

To measure the arterial thrombus tendency we recourse to the prothrombin time (PT) and partial thromboplastin time (PTT) which were found to be higher in palm oil, palm olein and corn oil.

Animal studies carried out by Hornstra et al and Rand et al (32) (33) suggested that palm oil had desirable influences on thrombotic tendency, blood platelet aggregation and eicosanoid biosynthesis.

The results reported suggested that palm oil was considerably less effective in promoting clotting than would have been anticipated on the basis of its fatty acid composition. Rand et al (33) suggested that the discrepancy between the predicted effect on clot formation and that observed in the experiment could be accounted for by reference to the tocopherols and tocotrienols contents in the oil, suggesting that among these component lies the ingredients reponsible for the anomalous behaviour.

Therefore, further studies especially designed to investigate the effect of dietary palm oil and palm olein based nutritional products on plasma lipoproteins and prostaglandin metabolism are needed.

\section{REFERENCES}

1. David, R., Erickson (1983).- "Soybean VS. palm oil then characteristics and utilization".- Presented at The Korean Society of Food Science and Technology "Special Seminar", Seoul, Korea, 1.983.

2. Imaizumi, K., Nagata, J.I., Sugano, M., Maeda, H. and Hashmoto, Y (1990).- "Effect of dietary palm oil and tocotrienol concentrate on plasma lipids, eicosanoid productions and tissue fatty acid compositions in rats".- Agric. Biol. Chem. 54, 963-972.

3. Chong, Y.H. (1987).- "New finding and facts on palm oil".- Nutrition Reviews 45, 205-207.

4. Sundram, K., Khor, H.T. and Ong, A.S.H. (1990).- "Biochemical and nutrition studies on palm oil".- Proc. Mal. Biochem. Soc. Conference (11), 28-31. 
5. Sundram, K. and Ong, A.S.H. (1986).- J. Am. Oil Chemists' Soc. 63 (4).

6. Du Plessis, L.M., Van Twisk, P., Van Niekerk, P.J. and Steyn, M (1981).- "Evaluation of peanut and cottonseed oils for deep frying".- J. Am. Oil Chemists' Soc. 58, 575-578.

7. Pazola, Z., Gawecki, J., Buchowski, M., Korczak, J., Jankun, J. and Grzeskowiak, B. (1983).- "Choice from simple methods for quality control of frying fat during frying of potato products".- Fat Science, Proc. $1^{\text {th }}$ ISF Congress, Budapest, 769-777.

8. Croon, L.B., Rogsted, A., Leth, T. and Kiutamo, T. (1986).- "A comparative study of analytical methods for quality evaluation of frying fat".- Fette Seifen Anstrichmittel 88, 87-91.

9. Briggs, G.M. and Williams, M.A. (1963).- "Composition of salt mixture".Fed. Proc. (22), 261-263.

10. Morcos, S.R. (1967).- "Composition of vitamin mixture".- Br. J. Nutr. (21), 269-271.

11. Ellefson, R.D. and Caraway, W.T. (1982) - "Determination of total lipid using the phosphoric acid vanillin reaction. In fundamentals of clinical chemistry".- Ed. by Tietz, N.W..- W.B. Saunders Company, Philadelphia, 292-294.

12. Allain, C.C., Poon, L.S., Chan, C.S. and Richmond, W. FU. P.G. (1974). - "Enzymatic determination of total serum cholesterol".- Clin. Chem. (20), 470-475.

13. Bucolo, G. and David, H. (1973).- "Quantitative determination of serum triglycerides by the use of enzymes".- Clin. Chem. (19), 476-482.

14. López Virella, M.F., Stone, P., Ellis, S. and Colwell, J.A. (1977)."Cholesterol determination in high density lipoprotein separated by three different methods".- Clin. Chem. (23), 882-884.

15. Husdonm, Z.K. (1968).- "Determination of serum phospholipids".Clin. Chem. (14), 222-224.

16. John, V. Dacie and Lewis, S.M. (1991).- "Practical Haematology".Seventh Edition, 281-284.

17. Weikowitz, J., Ewen, R.B. and Cohen, J. (1976).- "Introductory statistics for the behavioral sciences".- 2 nd Edition.- Academic Press, New York, 140-164.

18. Seham, A.T. and Maher, M.W. (1989).- "Biological responses of rats fed cotton seed oil used for repeated frying of potatoes".- J. Home Economic in Egypt (53), 95-100.

19. Majumdar, S., Bhattacharyya, A.C. and Bhattacharyya, D.K. (1986)."Nutritional evaluation of fractionated randomized palm oil and vanaspati".- J. Food Sci. Technol. 23, 321-325.

20. Habidah Abdul Hamid, Alini Marzuki and Rohani Kadir (1988).Proceedings of National Conference on Oil Palm/palm oil, 11-15 October, Kuala Lumpur.
21. Jacotot, B. and Beaumont, J.L. (1977).- "Dietary fats, lipidemia, and blood coagulation".- Nutr. Dieta 25 (Nutr. Aspects Fats), 108.

22. Stoddart, A.M., Knight, E., Adkins, J. and Criss, W.E. (1983).- "The effect of dietary vegetable fats on the growth of Morris hepatoma 7800".- J. Nutr. Growth Cancer 1, 147-150.

23. Quazi, S. and Yoshida, A. (1985).- "Influence of unsaturated acid saturated fats on lipid metabolism in rate fed either PCB or cholesterol".Nutr. Rep. Intr. 31, 535-546.

24. Tony, K.W.Ng., Hassan, K., Lim, L.B., Lye, M.S. and Ishak, R. (1991)."Nonhypercholestetrolemic effects of a palm oil diet in malaysian volunteers".- Am. J. Clin. Nutr. 53, 1015S-1020S.

25. Murakumi Chiaki, Chimi Kenji, Maruyama Takenori, Kanematsa Hiromu, Nijya Isao, Shimura Mitsuo, Mizutani Huruo and Hirai Choichiro (1990)."Effect of Processed Oils and Fats on Cholesterol Metabolism. I. Effect of Fractionated Palm Oil".- Yukagaku 39, 472-480.

26. Grundy, S.M. (1986).- "Comparison of monounsaturated fatty acids and carbohydrate for lowering plasma cholesterol".- N. Engl. J. Med. 314, 745-748.

27. Hornstra, G. (1987).- "Dietary lipids and cardiovascular disease. Effects of palm oil".- International Oil Palm/palm oil Conferences, 29 June - 1 July, Kuala Lumpur.

28. Qureshi, A.A, Qureshi, N., Ong, A.S.H., Gapor, A., De Witt, G.F. and Chong, Y.H. (1987).- "Minor constituents of palm oil. Nutritional considerations".- Paper presented at Symposium on Palm Oil Utilization and Nutrition PORIM-TAS Mission to USA.

29. Lim, J.B., Tony, K.W.Ng., Khalid Hassan, Lye, M.S. and Roshidah Ishak (1988).- Proceeding of National Conference on Oil Palm/palm oil, 11-15 October, Kuala Lumpur.

30. Sugano, M. and Imaizumi, K. (1991).- "Effect of palm oil on lipid and lipoprotein metabolism and eicosanoid production in rats".- Am. J. Clin. Nutr. (53), 1034S-1038S.

31. Bandet, M.F., Dachet, C., Lasserve, M., Esteva, O. and Jacotot, B. (1984).- "Modification in the composition and metabolic properties of human low density and high density lipoproteins by different dietary fats".- J. Lipid Res. 25, 456-468.

32. Hornstra, G., Hennissen, A.A.H.M., Tan, D.T.S. and Kalafusz, R. (1987). - "Fat Production and Consumption Technologies and Nutritional Implication".- NATOASR, Series A, Life Sciences, New York, 69-82.

33. Rand, M.L., Hennissen, A.A.H.M. and Hornstra, G. (1988).- "Effect of dietary Palm oil a arterial thrombosis, platelet responses and platelet membrane fluidity in rats".- J. Lipids (23), 1019-1023.

(Recibido: Junio 1992) 